Geopolítica(s) Revista de estudios sobre espacio y poder ISSN: 2172-3958

\title{
In Memoriam of Ron Johnston
}

Ryan Weichelt ${ }^{1}$

Cómo citar: Weichelt, R. (2020). In Memoriam of Ron Johnston. Geopolítica(s). Revista de estudios sobre espacio y poder, 11(1), 21-23.

In 2003 at the annual Association of American Geographers (AAG) meeting in New Orleans, Louisiana I presented one of my first papers as a master's student. This paper was a rather simplistic analysis of election results for college communities throughout the United States. Upon the eventual release of the session schedules I was left stunned with the addition of Ron Johnston as a discussant for my session on new research trends in American electoral geography. I quickly questioned how could I be placed in a session with "the" Ron Johnston? This question quickly gave way to fear and anxiety that I had to present in front of him. Unfortunately, Ron's plane was delayed, and he could not attend the session, but this small story is a testament of what Ron Johnston meant not only to electoral geography, but to the discipline of geography.

In all the current chaos of the world, loss has become all too common place. For the school of Geography, the sting of loss was felt more with the sudden passing of Ron Johnston on May 29, 2020. In the realms of Human and Political Geography few names stand out more than Ron Johnston. Though my personal interactions with Ron were rather limited, my intellectual interactions with his work were often, as few academics can compare to the productivity of Ron's research.

As an electoral geographer the loss of Ron Johnston to this small subset of political geography will be painful. Though, in his loss Ron's dedication and passion for the discipline has provided current and future scholars a blueprint on how to succeed. For any beginning electoral geographer there is one book that is a must read. This book is Peter Taylor and Ron Johnston's Geography of Elections (1979). This book introduced the broader public to the way's geography can help understand elections and politics at the local level. In particular, Chapter Five, "The Neighborhood Effect," had a profound influence on me. This chapter examined, "... the reasons why different people in the same place vote in the same way while similar people in different places vote in different ways" (p.222).

Department of Geography and Anthropology, University of Wisconsin-Eau Claire (Estados Unidos)

E-mail: weicherd@uwec.edu 
The ability to combine a multitude of social science theories into a geographic understanding of human activity was what Ron did best. His continued work with neighborhood analyses also highlighted his contribution to methodological advances combining quantitative methods and electoral studies. These studies not only included voting analyses, but also studies on campaign financing, boundary formations, and urban studies (to name just a few). His pioneering book, Multivariate Statistical Analysis (2008), brought these vast experiences together that became a common read for many graduate students around the globe.

Through an academic career that spanned five decades, Ron Johnston authored or coauthored 467 journal articles, 127 book chapters, 18 books, and edited of coedited 10 additional books. However, I feel his legacy will be his ability to push fellow geographers and researchers to continually question their roles in their discipline. One of my early readings of Ron Johnston was his 2001 piece in Political Geography, "Out of the 'moribund backwater': territory and territoriality in political geography." This article provided a condensed thirty-year history of political geography and questioned its place in the overall study of politics by geographers. While giving well deserved credit to the impacts of other important political geographers like Peter Taylor, it also issued challenges to other political geographers to define its place in an ever-changing world.

These challenges did not apply just to political geography, but to the broader academic community as well. In 2011 he authored a rather pointed article in The Professional Geographer, "Promoting Geography (or Part of It) - Yet Again," in which he masterly criticized non-geographers for their lack of understanding of the field and geographers for their lack in confidence in their own discipline. Johnston wrote,

Geographers - both individually and collectively and much more than their colleagues in most of the other earth, environmental, and social sciencesfrequently appear somewhat paranoid about their discipline. They feel relatively ignored and undervalued, occupying an inferior position in the academic division of labor; the quality and relevance of their research is not recognized, and consequently they are not called on as often as they would like to apply their expertise in responding to major societal issues. (p.325).

Similarly, Johnston's desire for the history of geography also provided him a platform to not only provide resources for geographers, as seen in his seminal 1981 edited volume on the Dictionary of Human Geography (on its $5^{\text {th }}$ edition), but yet again challenged geographers to not be afraid to promote spatial thinking in a 2018 article, "Quantitative Methods I: The world we lost - or where we started from," and a 2019 article, "A Classic that wasn't: Statistical Geography and paths only later taken."

Geography is in a much better place because of Ron Johnston. We are all fortunate Ron left behind such a large treasure-trove of his thoughts, research, and ideas. This small tribute only highlights a few of his many contributions to the field. I believe the best way to honor Ron Johnston is to take time and read some of his many publications and take to heart his challenges to move the discipline forward and not be afraid to declare yourself a geographer! 


\section{References}

Johnston, R. J. (1980). Multivariate Statistical Analysis in Geography: A Primer on the General Linear Model. London: Longman.

Johnston, R. J. (Ed.). (1981). The Dictionary of Human Geography. Oxford: Blackwell Reference.

Johnston, R. J. (2001). Out of the "moribund backwater": territory and territoriality in political geography. Political Geography, 20(6), 677-693.

Johnston, R. J. (2011). Promoting Geography (or Part of It)-Yet Again! The Professional Geographer, 63(3), 325-331.

Johnston, R. J., Harris, R., Jones, K., Manley, D., Wang, W. W., \& Wolf, L. (2019). Quantitative Methods I: The World We Have Lost - or Where We Started From. Progress in Human Geography, 43(6), 1133-1142.

Johnston, R. J., \& Jones, K.( 2020). A Classic That Wasn't: Statistical Geography and Paths Only Later Taken. Progress in Human Geography, 44(2), 357-373.

Taylor, P. J., \& Johnston, R. J. (1979). Geography of Elections. New York: Routledge. 